\title{
Determinants of Balance of Trade in the Sri Lankan Economy
}

\author{
Erandi Weerasinghe and Tissa Ravinda Perera
}

\begin{abstract}
The Sri Lankan economy has experienced a balance of trade deficit over the past four decades and this paper attempts to identify the macroeconomic variables which have influenced such a situation. Thereby, this study is mainly focused on four exogenous variables including an endogenous factor which may affect the external balance of an economy. The model used in this study is developed for the first order autoregressive process as used by many research studies carried out in the recent past relating to this area, by using the quarterly data from the $2000 \mathrm{Q} 1$ to $2015 \mathrm{Q} 2$. According to the empirical results, it was observed that gross domestic product; volumes of imports and inflation rate have a significant impact on the balance of trade deficit in the Sri Lankan economy. A nominal exchange rate and direct foreign investments have not influenced the current situation. There is a positive relationship between the exchange rate and the trade balance which is not a significant factor and this result is not supported by the latest studies carried out. Thus, it can be concluded that the policy measures taken during the past four decades of Sri Lankan economic history regarding the exchange rate has had little less an influence in rectifying the external balance problem in Sri Lanka.
\end{abstract}

Index Terms-Balance of payment, Sri Lanka, economy, determinants.

\section{INTRODUCTION}

\section{A. Overview of Balance of Trade}

Balance of Trade (BOT) is the major component of the balance of payment of a country. It is the difference between exports and imports of a country made during a specific period of time. In the case of the value of its exports reporting an excess over the value of its imports over a period, that economy is accounted to have a favourable balance of trade. In opposition to the above scenario it is accounted an unfavourable (deficit) balance of trade. In general, it is believed that a favourable BOT indicates better economic conditions in a country by promoting an economic growth as BOT surplus may bridge the financial gap in the overall balance of payment. The fluctuations of BOT become major concerns especially for developing countries.

Under these circumstances, it is expected to examine the determinants of BOT in the Sri Lankan economy based on several macroeconomic variables.

Manuscript received October 12, 2018; revised January 5, 2019.

The authors are with Department of Management \& Organization Studies Faculty of Management \& Finance, University of Colombo, Sri Lanka (e-mail: erandiveiw@yahoo.com, adrtissaperera@yahoo.com.au).

\section{B. Brief Look at the Sri Lankan Economy since Her Independence}

During the first decade after independence in 1948 Sri Lanka continued to remain as an open trading nation with only relatively insignificant trade and exchange rate restrictions and liberal domestic policies. Trade restrictions were initially introduced in response to growing Balance of Payment (BOP) difficulties. This supported to direct private sector production activities in line with national priorities.

Sri Lanka was one of the greatly inward-oriented and regulated economies by the end of the mid-1970s. During this period, the economy was characterised by stringent trade, exchange controls and pervasive state interventions in almost all the economic activities in the country. In addition, the foreign investment policy continued to remain extremely liberal by permitting the setting up of affiliation within Sri Lanka to undertake the domestic production which was previously fulfilled by their overseas entities until the mid1960s.

During the period from 1970-1977 extensive nationalisation measures were taken to promote the private sector into the economy by initiating various economic control activities. Among them, import substitution industrialisation was the major solution identified by the Sri Lankan policy makers to fill the vacuum in self-sustained growth for reducing the heavy dependence of the economy on imports. As a result of these policy changes, consumer goods imports were reduced drastically, and this was achieved at the expenses of increased reliance on imported capital goods and raw materials. As a result the growth dynamism of the newly established industrial sector tended to reflect a close functional relationship with the traditional export industries.

In 1977, Sri Lanka embarked on extensive economic liberalisation process, in response to the dismal economic outcome of the inward-looking strategy. By initiating this, Sri Lanka became the first economy in the South Asian region to introduce such reform. Under this process, significant trade reforms- replacing quantitative limitations on imports with tariffs and amending the tariff structure to achieve better consistency was introduced during 1977-79 as a first round of the reform. In addition, restrictions on foreign investment were reduced with new incentives for export oriented foreign direct investment under the free trade zone scheme. Interest rates were adjusted to levels above the rate of inflation as a support to the financial reform. A programme for privatisation of public enterprises was also another key decision taken under this extensive economic liberalisation process. With the expectation of enhancing export oriented industries, exchange rate 
realignment was introduced as well as intensives for nontraditional exports. However, the momentum of this reform progress vanished in the early 1980s with the major change in the political status of the country which continued to present a situation under different exchange rate regimes.

\section{Trends of the Trade Deficit in Sri Lankan Economy}

The Sri Lankan economy continued to be heavily dependent on foreign trade and trade policy since independence as it was dominated by deteriorating terms of trade. In general terms, a trade deficit is not always inherently problematic. Its problem depends on its persistence, size, and composition and causes of the deficit that determine it and to what extent the trade deficit is a matter of concern. The Sri Lankan trade deficit is mainly due to the following reasons.

- Size: It represented $11.1 \%$ of GDP at the end of 2014 and has reported a slight decline by $0.02 \%$ when compared with the previous year.

- Cause: The historical data show that the main reason for the expanding trade deficit is mainly due to decline in exports as well as increase in imports.

- Trend: over the last decade it has reported for an increasing trend.

Fig. 1 and Fig. 2 represent the trends of Balance of Trade in Sri Lanka and growth fluctuations of the two main categories of the trade account recorded over the last 15 years from 2000 to the second quarter of 2015.

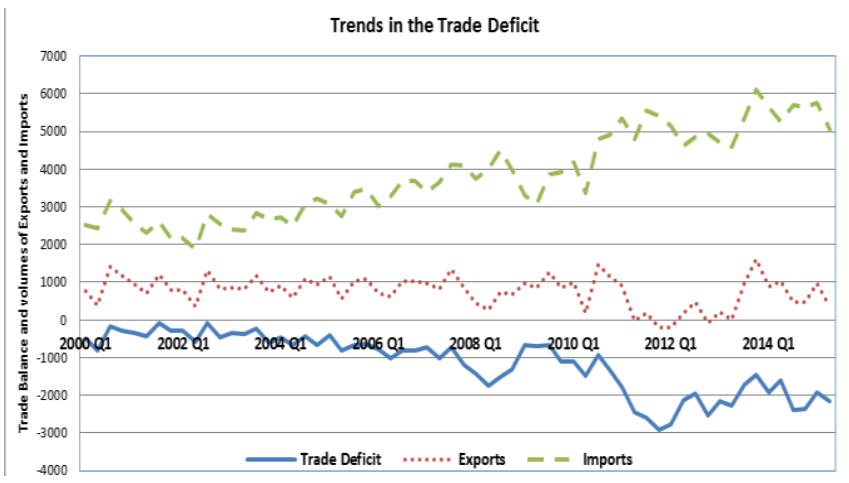

Fig. 1. Trends of balance of trade in Sri Lanka.

Amongst the developing countries, Sri Lanka has been an early mover in trade liberalization and benefited from it in the 1980s and 1990s. However, that trend changed in the last decade mainly due to the policy decisions taken by the policy makers who had the expectation of positioning the economy to the growth path through import substitutions. Thereby, a significant curtailment in the trade deficit was achieved with heavy reduction of imports.

On the other hand that decision did not positively affect the Government revenue as the import taxes reduced significantly. During the 1990 s to 2000 , export promotion schemes were launched in order to rectify the trade balance problem and among several policy decisions, the export oriented Foreign Direct Investment has played a major role in the economic dynamics of Sri Lanka.

Despite the policy changes that took place to improve the trade deficit in Sri Lanka, it was noted that after 2000, the trade deficit accumulated significantly mainly due to a decline in exports as against the huge growth in imported goods (See Fig. 2).
Growth Fluctuations: Imports Vs Exports

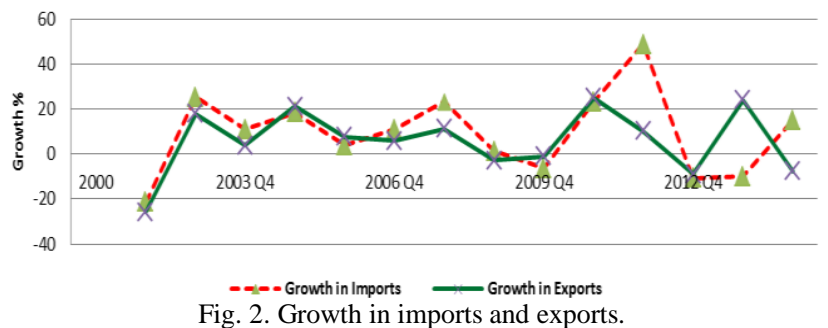

\section{Research Issue and Significance of the Study}

Sri Lanka has been suffering from balance of trade deficit during the past considerable number of years. When compared with other SAARC counties, reported figures relating to the Sri Lankan economy show a relatively higher percentage of GDP than the other countries, except the Maldives (See Table I).

TABLE I: CURRENT ACCOUNT BALANCE AS \% OF GDP- SAARC

\begin{tabular}{|l|c|c|c|c|c|}
\hline \multicolumn{1}{|c}{ Country } & 2010 & 2011 & 2012 & 2013 & 2014 \\
\hline Bangladesh & 1.0 & -0.1 & 1.9 & 1.4 & -1.0 \\
\hline India & -3.2 & -3.4 & -5.0 & -2.6 & -1.5 \\
\hline Maldives & -8.4 & -16.0 & -7.3 & -4.4 & -6.3 \\
\hline Pakistan & -0.8 & -1.0 & -1.0 & -1.9 & -1.4 \\
\hline Singapore & 23.7 & 22.0 & 17.2 & 17.9 & 19.1 \\
\hline Nepal & -0.8 & 1.5 & 3.1 & 6.0 & NA \\
\hline Sri Lanka & -2.2 & -7.8 & -6.8 & -3.8 & -2.2 \\
\hline
\end{tabular}

Source: World Bank data

The current account balance as a percentage of GDP provides a signal of the international competitiveness level of a country. Generally, a well-built surplus current account (such as Singapore) balance of a country reflects that economy is heavily depending on export oriented industries with high savings ratings. In contrast, a country accounting a deficit in its current account highly depends on imports which indicating a low savings rates with greater personal consumption rates as a percentage of disposable income. This study examines the determinants of the balance of trade deficit of Sri Lanka by considering macroeconomic variables. Although there is literature on external sector developments (trade balance, balance of payment) related studies on most of the other developing countries, emerging economics as well as several developed countries, show that little attention has been paid so far on trade balance/balance of payment related studies in the Sri Lankan economy.

\section{E. Research Hypothesis}

The major hypothesis of this study is to examine the selected macroeconomic variables that are important and to what extent they explain the balance of trade the in Sri Lankan economy. The analysis is based on quarterly data obtained from the data base of the Central Bank of Sri Lanka for the period 2000 Q 1 to 2015 Q 2.

$H_{0}=$ the selected macroeconomic variables have an impact on the Balance of Trade in Sri Lanka.

$H_{1}=$ the selected macroeconomic variables have no impact on the balance of trade in Sri Lanka.

\section{F. Scope and Methodology of the Study}

In this study, the balance of trade is taken as the 
dependent variable and other few macroeconomic specific variables as explanatory variables which are selected based on the literature review carried out for other developed as well as developing countries and based on the writers' experience and own judgment in the context of the Sri Lankan economy. The rest of this paper is organized as follows: Section II represents the relevant literature on the study. Section III describes the model, the dependent and independent variables and describes the sample and methodology used. Sections IV and V present the results from the empirical analysis and conclusion, respectively.

\section{REVIEW OF LITERATURE}

A considerable number of empirical studies on the balance of trade and overall balance of payment have been carried out in the developing as well as developed economies during the last three decade. Among these studies the main attention was given to study the relationship between exchange rates and trade balance, determinants of trade and overall BOP balance, J-curve effect and holding of Marshall-Lerner conditions, impact of trade balance on the economic growth of an economy etc. These studies have ended up with different results which supported the existing findings or were contradictory to existing knowledge, depending on the identical economic factors relating to each economy.

\section{A. BOT Related Studies in Developed Economies}

Most recent researches on the developed countries have been focused on the US economy as it is recording a considerable amount of negative trade balance and the economists argue that it stimulates global demand which would ultimately create global imbalances also. Under these circumstances, most of the studies carried out after 1970s relating to this area are focused on the US economy. However, it was noted that different models were used by different researchers and ended up with somewhat complex and ambiguous results. The US trade deficit as against the 23 largest US trading partners, showed that the country with which the US has the largest trade deficits do not exhibit any long-run relationships, indicating that any selfcorrecting mechanism on the trade account is either nonexistent or slow in these cases [1]. Further, the presence of a long-run relationship is most apparent in the countries with which the US has a trade surplus. Taken together, these results provide evidence that it is possible to have continued growth in the US trade deficit. It has been presented a global macroeconomic view including repercussions of the existence of the US trade deficit [2]. Thereby, he argued that continued massive US trade deficits which have been growing for the last two decades could lead to a fall in the dollar, which in turn could result in sharply higher interest rates and recession in the US and slower economic growth of the world economy. Further, he pointed out that inadequate US savings and extreme savings in some emerging economies (such as China, Japan ) as well as S. Arabia including OPEC countries are leading to significant capital inflows to the US an overvalued dollar and an unsustainable trade deficit.

An empirical study carried out on the determinants of US trade balance with Australian trade balance showed that the most important determinant of Net Export (NE) is the price ratio (USA relative to Australia), followed by the lending rate ratio, GDP ratio, money supply ratio and the real exchange rate [3]. Those variables have explained $93 \%$ of the variation in NE. Further, he recognised that there was a positive long run relationship between NE and the exchange rate. The effects on J-curve of trade balance in Canada have been examined and results showed that real depreciation of the Canadian dollar has short run effect on the trade balance of two thirds of her industries [4]. For this study he has used export and import data over the period 1962-2004 from 152 commodities and the bounds testing approach to cointegration and error-correction modelling were used to predict these results. A more general model for monetary variables that affect balance of trade and studied whether a restricted version that embodied neutrality of money could be ignored [5]. This "general to simple" approach is useful in providing a structured empirical framework and in allowing one to rigorously test fundamental hypotheses regarding trade balance determinants. The evidence suggests that trade balance fluctuations were determined predominantly by temporary changes in real output and real government spending and by changes in the expected US real interest rate. Based on the study carried out on the exchange rates and the trade balance in Germany, pointed out that the J-curve phenomenon refers to the initial deterioration of the trade balance and its eventually recovery in response to an exchange rate evaluation [6]. On the other hand, the US economy experienced continued deterioration in its trade balance despite a declining dollar exchange value in the 1980s. This condition is analysed with the exchange rate and trade balance using data from the period 1975 to 1989 and the results indicated a "delayed J-curve" effect in Germany. A study focused on the existence of Jcurve effect and the relationship between real effective exchange rate and Trade balance of Australia [7]. Accordingly, there was some proof to imply the existence of a short-run delayed J-curve effect and a positive long-run response of the trade balance to a depreciation of the real effective exchange rate. On the other hand, no such short or long-run impacts have been established in response to changes in the terms of trade in Australia during the period 1965: 1-1993:3. Turkey's liberalized trade system permitted both the real exchange rate and domestic and world incomes to influence the balance of trade in the long run. These longrun results are supported by short-term estimations that also exhibit a clear role for the exchange rate in the short run based on the historical data used for the period 1969 to 1993 [8].

A study carried out to identify the impact of exchange rate volatility on the real imports of the United Kingdom from Canada, Japan and New Zealand during the period1980-2003 [9]. For this study the Johansen multivariate co-integration method and the constrained error-correction method have been used. Based on the results, he concluded that the existence of a significant positive effect of the exchange rate volatility on real imports. The persistence of the US trade balance in the late 1980s and found that US imports shows less responsiveness to the fall in the dollar while increasing foreign competition facing 
US exports[10]. The impact of exchange rate volatility on Germany was investigated in 1997 for the period 1973:41992:9 with the ARCH model [11]. The results were contrary to many papers previously published as the effects of volatility are found to be positive and statistically significant for the period under review. The study carried out recently relating to the US trade deficit, has explained that the US trade deficit has refocused attention upon the responsiveness of trade flows to exchange rate and income changes [12]. For his study the estimate of import and export equations over a period across the 1990s were used and the outcome indicated that a low responsiveness of imports to exchange rate changes and a diminution (but not disappearance) of the income elasticity asymmetry occurred. The combination of low price elasticity of imports with the present size of the trade deficit means that any reduction of the trade deficit will necessarily be accompanied by large exchange rate and income trend adjustments.

\section{B. BOT Related Studies in Developing and Emerging Economics}

Several empirical studies have been carried out for an individual developing country relating to the determinants of the trade deficit. According to these studies common independent variables have been considered such as real exchange rate, trade volumes, foreign direct investments, domestic income, foreign income and inflation rate against the trade deficit. However, some studies country specified variables such as international reserves, money stock, domestic consumption, domestic credit, fiscal balance and interest rate also have been used.

A resent empirical study carried out on the effect of trade deficit on the Pakistan economy, has concluded that GDP, FDI, Exchange rate have moderate correlation with trade deficit except trade volumes [13]. The latest empirical evidence provided from the Saudi Arab economy shows a significant relationship between exchange rate fluctuations and trade balance in the long run but not in the short run [14]. The author of this study has used annual data series from 1982 to 2011 by using the PPP model. The foreign exchange rate reforms, BOT and economic growth in China by using monthly data from 1986:1 to 1997:1 using IMF international financial statistics [15]. Real exchange rate, real domestic income, foreign real income, exchange rate premium and international reserves were used to study the impact on BOT. According to the results of this study, he concluded that the effect of the real effective exchange rate on the real trade balance appears to be moderate in the long run. Further, he has shown that the short run version of the model does not indicate the existence of a J-curve effect in the Chinese economy. A study was carried out on the effect of exchange rate on Ghana's external trade for the period 1986-2005[16]. Accordingly, they have concluded that the import demand is elastic with respect to the real effective exchange rate in both the short and long run but export is inelastic with respect to real effective exchange rate in both periods. Further, they have found out that a long run linear relationship exists among the imports, exports and trade balance, domestic income, foreign income and price index. A comparative study between Asia and Europe for the determinants of current account deficit has been carried out for the last two decades from 1980 by using GDP, Imports, Exports, Exchange rate, Inflation rate and income receipts and concluded that all variables used for the study were significant in both Asia and Europe [17].

Based on the research study carried out on trade balance of Colombia, concluded that the exchange rate does play role as in determining the short and long run equilibrium behaviour of the Colombia trade balance and has shown that there is one co-integrating relationship between the trade balance, exchange rate, money and Income in the long run [18]. A positive effect of exchange rate devaluation on the trade balance seemed enhanced if accompanied by reduction of stock of money and an increased income has analysed the determinants of trade in India by using annual data from $1972 / 73$ to $2010 / 11$ by considering the real effective exchange rate, domestic consumption, FDI, real income to the rest of the world (foreign income) as independent variables as against its trade balance [19]. As per the results of the study it has been identified that FDI, foreign income have significant impact on trade balance and the rest of the variables used accounted for negative impact. Determinants of Argentina's External Balance studied concluded that export sensitivity to world commodity prices, domestic and economic activity of Brazil, combined with a high income elasticity of imports are key determinants of Ag's trade balance [9]. Macroeconomic Determinants of Balance of Payment in Namibia have been analysed, and ended up with the conclusion that effects of GDP, expansion of export have a positive impact on current account balance as well as the overall balance of payment [20]. Further, they have found that a positive impact of interest rate on BOP and an improvement in the fiscal balance is also associated with an improvement in the BOP. A study made an effort to identify the relationship between exchange rate and the trade balance by using quarterly data from 1970 to 1988 for a variety of 30 developing countries [21]. However, he was unable to find a strong stable effect of the exchange rate on the trade balance among those developing countries. A study carried out on the existence of the J-Curve in African countries (i.e. Burundi, Egypt, Kenya, Mauritius, Morocco, Nigeria, Sierra Leone, South Africa and Tanzania) has shown that there was no support for the short-run J-Curve effect in the countries under study [22]. However, despite the short run results they have identified that the long-run impact of real depreciation was favourable only in the cases of Egypt, Nigeria, and South Africa.

To my best knowledge, there are no similar published empirical studies on determinants on trade deficit in the Sri Lankan economy and this study fills an important gap in the literature. However, few of the Sri Lankan trade balance related studies have focused on the relationships against the exchange rate regimes and the fluctuations in trade balance.

\section{ANALYTICAL FRAMEWORK}

\section{Basic Theoretical Background Relating to the Balance of Trade}

Based on the economic theories relating to the BOT, it can be categorized under 3 classifications viz. (i) Elasticity approach (ii) Absorption approach and (iii) Monetary 
approach. Under the elasticity approach $(\varepsilon d=$ elasticity of demand measured by the equation $(\% \Delta Q d) /(\% \Delta P)$ and this represents the responsiveness of quantity demanded to changes in prices which is usually negative. This approach totally depends on the foreign exchange equilibrium of a country. Accordingly, any devaluation or revaluation (depreciation and appreciation of domestic currency) will directly affect the BOT depending on the elasticity of such goods.

On the other hand the Absorption Approach reflects the national income of a country as: $Y=C+I+G+(X-M)$ where $Y$ denotes national income, $C=$ private domestic consumption, $I=$ Private domestic investments, $G=$ Government spending, $X=$ exports and $M=$ imports. If it is considered that the total domestic spending or absorption is " $A$ " then $A=C+I+G$. There by; $Y-A=X-M$.

Accordingly, if $Y>A$, then $X-M>0$ or BOT $>0$ and if $Y<A$, then $X-M<0$ or BOT $<0$. So, when $Y<Y^{*}$ (at full employment level), devaluation would improve BOT. However, when $Y>Y^{*}$, devaluation would increase $X-M$ and leading to create inflation.

The Monetary approach concludes that any foreign exchange intervention to the domestic market will impact on the domestic money supply and directly affect to the domestic interest rate as well. As a consequence, the domestic price level will change.

Consequently, the model developed for this study is based on these three different theoretical views for the analysis of the trade balance in Sri Lanka and the selected variables are based on such circumstances as well as in the context of the Sri Lankan economy.

\section{The Model}

This paper examines the determinants of the trade deficit in Sri Lanka by applying general multiple regression models as applied by previous studies to ensure the direction of causality between variables [1], [4], [13], [21].

$$
Y_{t}=f\left(\mathrm{GDP}_{t}, \mathrm{VIM}_{t}, \mathrm{FDI}_{t}, \mathrm{ER}_{t}, \mathrm{INR}_{t}\right)
$$

According to this, the econometric model based on the First-order autoregressive process for the Trade deficit in Sri Lanka for $t$ years is contrasted as follows:

$$
Y_{t}=\alpha+\underset{i=1}{\sum \beta_{i} X_{i, t}}+U_{t}
$$

Fig. 3. The model.

where;

$$
Y_{t}=\text { Balance of Trade (BOT) }
$$

$\alpha=$ Regression constant term,

$\beta_{i}=$ Regression coefficients for the respective variable determinants of BOT

$X_{i, t}=$ Vectors of bank specific determinants such as ,

GDP $=$ Gross Domestic Products

VIM $=$ Volume of imports

FDI $=$ Foreign Direct Investments

$\mathrm{ER}=$ Exchange Rate

$\mathrm{INR}=$ Inflation Rate

$u_{t}=$ Error Term.

\section{E. Determinants of Trade Balance and Variable Selection Dependent Variable}

For this study balance of trade is considered as reliance variable which represents the differences between exports and imports of an economy during a given period of time. In the literature plenty of studies were carried out to identify the economic impact of a country's trade balance (mainly trade deficit). Some studies have considered the overall balance of payment as the dependent variable. However, when considering the Sri Lankan scenario it is more valuable to study the BOT as it represents continuous deficit over almost the last four decades.

- Independent Variables

Gross Domestic Product (GDP) is the monetary value of all the finished goods and services produced within a given period of time. GDP includes all spending (private and Government/public consumption), investments and exports minus imports. Therefore, GDP measures a nation's overall economic activities carried out within the boarder of a country. Accordingly, GDP is considered as one independent variable for this study as used by several researchers [13], [17].

The volume of imports is also considered as another determining variable of the BOT as the Sri Lankan economy experiences a significant amount of growth in imports when compared with its growth rate in exports. Under this circumstance, the import volumes is a major contributory factor for recording a huge trade deficit in the Sri Lankan economy over a considerable period of time. The values of all imported goods and services in terms of the Sri Lankan currency are used for this study as considered by numerous studies in the past. i.e. [4], [13], [16], [17].

Foreign direct investments (FDI) accounted for the net inflows of investment including the sum of equity capital, reinvestment of earnings, other long term capital and shortterm capital borne in an economy by investors in the rest of the world. In recent decades FDI becomes a growth incentive tool for developing countries and more attention has been paid to study its impact on economic growth. Therefore, as a developing country, it is worthwhile to consider its impact on BOT. However, few studies have taken into consideration the impact of FID on the BOT, i.e. [2], [13].

Exchange rate is also one of the major variables which significantly direct impact the overall balances of BOT as well as BOP. On the other hand, inflation rate is considered based on the monetary approach method of BOT which would ultimately affect the domestic price level which is represented by the inflation rate.

Tables II and III indicate the definitions and notations of each variable used in this study along with the rationale of relationship expected with each variable and BOT.

\section{F. Data and Methodology}

For this study quarterly data relating to the Sri Lankan economy have been used for the period 2000q1 to $2015 \mathrm{q} 2$ from the statistics data base of the Central Bank of Sri Lanka. As there were no significant and unexpected changes relating to the BOT as well as other independent variables for the prior periods, the sample was restricted to the last decade for this study. 
TABLE II: VARIABLE DEFINITION AND NOTATION

\begin{tabular}{|l|l|l|l|l|}
\hline $\begin{array}{c}\text { Nature of the } \\
\text { Variables }\end{array}$ & \multicolumn{1}{|c|}{ Variable } & \multicolumn{1}{|c|}{ Description } & Notation & $\begin{array}{l}\text { Expected } \\
\text { Relation }\end{array}$ \\
\hline Independent Variable & Balance of Trade & Difference between exports and imports. & BOT & \\
\hline \multirow{5}{*}{ Dependent Variables } & Gross Domestic Products & $\begin{array}{l}\text { monetary value of all the finished goods and services produced } \\
\text { within the country }\end{array}$ & GDP & Positive (+) \\
\cline { 2 - 6 } & Volumes of Imports & $\begin{array}{l}\text { The values of all imported goods and services in terms of } \\
\text { domestic currency. }\end{array}$ & VIM & Negative(-) \\
\cline { 2 - 6 } & Foreign Direct Investments & Net inflows of investment & FDI & Positive (+) \\
\cline { 2 - 7 } & Exchange Rate & Nominal exchange rate & EX & Negative $(-)$ \\
\cline { 2 - 7 } & Inflation Rate & Measured by CCPI & Negative $(-)$ \\
\hline
\end{tabular}

TABLE III: DETERMINANTS OF BALANCE OF TRADE DEFICIT

\begin{tabular}{|l|c|l|}
\hline \multicolumn{1}{|c|}{ Variable } & $\begin{array}{c}\text { Expected } \\
\text { Relationship }\end{array}$ & Reason for the Relationship \\
\hline $\begin{array}{l}\text { Gross Domestic } \\
\text { Products }\end{array}$ & Positive & Trade considered as an influence factor to the economic growth when there are BOT or overall BOP surpluses. \\
\hline Volumes of Imports & Negative & Increase in imports will accounted negative BOT \\
\hline $\begin{array}{l}\text { Foreign Direct } \\
\text { Investments }\end{array}$ & Positive & $\begin{array}{l}\text { Spill overs from FDI will accelerate total factor productivity of domestic firms and thereby discourage imports } \\
\text { or growth in exports which ultimately improves the BOT }\end{array}$ \\
\hline Exchange Rate & Negative & Devaluation of exchange rate will encourage exports and thereby improve BOT. \\
\hline Inflation Rate & Negative & $\begin{array}{l}\text { Surpluses in BOT will lead to reduction in domestic prices as export driven economy would discourage imports } \\
\text { due to lower price level in the domestic markets. }\end{array}$ \\
\hline
\end{tabular}

\section{EMPIRICAL RESULTS}

\section{A. Descriptive Statistics}

The descriptive statistics of all variables used for the regression model are presented in Table IV. Main figures, including mean, standard deviation, min and max are generated to get an overall idea about the data used in the model. Accordingly, a larger standard deviation is accounted for "GDP" values when compared with other variables. It is revealed that GDP has more significant variance than other variables. However, other macro variables such as exchange rate and inflation rate have shown relatively low standard deviations, implying that the macroeconomic conditions in Sri Lanka remain reasonably stable during the period under review.

The time series of all variables used in this study over the period from 2000q1-2015q2. GDP was exhibiting an overall upward trend over the observed period for 62 observations. On average, volumes of imports also showed an increasing trend even though there was a significant decline reported in 2008-2009. In contrast, exchange rate indicated an increasing trend over the period under study by reflecting a smaller decline after the year 2010 and ultimately resulted in a huge growth in exchange rate by the end of the $2^{\text {nd }}$ quarter of 2015 indicating a worsening of the BOT. However, FDI show on average an increasing trend which shows considerable fluctuations during the past 4 years. Time series plots on inflation rate reflects an overall an declining trend even though it represents a major increase during 2008-2009.Accordingly, it was noted that all variables used in this model have reflected major fluctuations during the later period of the global financial crisis existed which indicates that its adverse impact also affects to the small open economies as well.

TABLE IV: DESCRIPTIVE STATISTICS OF THE VARIABLES

\begin{tabular}{|l|l|l|l|l|l|}
\hline Variable & OBS & Mean & SD & Min & Max \\
\hline TB & 62 & -1141 & 776 & -2911 & -79 \\
\hline GDP & 62 & 586689 & 203144 & 267 & 1256 \\
\hline IM & 62 & 3042 & 1299 & 1358 & 5619 \\
\hline FDI & 62 & 120 & 89 & 15.4 & 386 \\
\hline ER & 62 & 109 & 14 & 83 & 133 \\
\hline INF & 62 & 9 & 6 & 2.1 & 28.2 \\
\hline
\end{tabular}

A correlation matrix for all independent variables was also generated to detect a multicollinearity problem in the model. As per the results indicated in Table $\mathrm{V}$, there are reasonably low correlations existing among the independent variables, thus improving the reliability of the regression results (considered as having no multicollinearity problem since none of the correlation coefficients are more than $0.57)$.

TABLE V: COEFFICIENT CORRELATION BETWEEN THE DEPENDENT VARIABLES

\begin{tabular}{|c|c|c|c|c|c|}
\hline Variable & GDP & IM & FDI & ER & INF \\
\hline GDP & 1.0000 & & & & \\
\hline IM & 0.5764 & 1.0000 & & & \\
\hline FDI & 0.4368 & 0.2704 & 1.0000 & & \\
\hline ER & 0.5407 & 0.5353 & 0.5527 & 1.0000 & \\
\hline INF & -0.3539 & -0.2318 & 0.0769 & -0.2788 & 1.0000 \\
\hline
\end{tabular}

\section{B. Stationarity of Series}

According to economic theory, all variables are required to be stationary before applying standard econometric techniques. Thereby, in order to verify whether the variables used in the model are stationary, the unit root test was used. For this study, Unit Rot test was carried out based on the Augmented Dickey - Fuller Test Equation with 4 lag levels as applied for quarterly data [14]. In general, stationarity implies that the mean, variance and autocorrelation of a variable do not change with time. The results indicate that the null hypothesis of GDP, VIM and ER can be accepted under $1 \%$ and $5 \%$ significance levels based on the two methods (with trend and without trend) which means that those variables are stationary at its level. Under these circumstances, to make the other two variables, FDI and INT stationary it is required to consider for first differencing. Accordingly, these variables are also stationary at its first differentiate level at $1 \%$ critical values as shown in the summary Table VI.

In order to ensure reliability of the output of the model used, it is required to verify the behaviour of the error term. This was confirmed by using the White-Heteroskedaticity 
test. As the test statistics indicate in the table VII, the existence of the Heteroskedaticity problem was sorted out by applying a robust test which gives different p- values while keeping the coefficients constant.

TABLE VI: RESULTS OF ADF TEST

\begin{tabular}{|c|c|c|c|}
\hline \multirow[b]{2}{*}{ 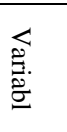 } & \multicolumn{2}{|c|}{ Test results } & \multirow{2}{*}{$\begin{array}{l}\text { First } \\
\text { and Difference } \\
\text { significant level }\end{array}$} \\
\hline & $\begin{array}{l}1^{\text {st }} \text { Method: Only } \\
\text { Intercept } \quad \text { (No } \\
\text { trend) }\end{array}$ & $\begin{array}{l}2^{\text {nd }} \text { Method: Trend } \\
\& \text { Intercept } \text { (with } \\
\text { trend) }\end{array}$ & \\
\hline GDP & $-2.856^{* *}$ & $-3.689 * *$ & \\
\hline VIM & $-5.747 * * *$ & $-4.305 * * *$ & \\
\hline ER & $-4.954 * * *$ & $-4.750 * * *$ & \\
\hline FDI & & & $-5.433 * * *$ \\
\hline INT & & & $-6.657 * * *$ \\
\hline \multirow[b]{2}{*}{ हैं } & \multicolumn{2}{|c|}{ Test results } & First Difference \\
\hline & $\begin{array}{l}1^{\text {st }} \text { Method: Only } \\
\text { Intercept } \\
\text { trend) }\end{array}$ & $\begin{array}{l}2^{\text {nd }} \text { Method: } \\
\& \text { Trend } \\
\& \text { Intercept (with } \\
\text { trend) }\end{array}$ & $\begin{array}{l}\text { and its } \\
\text { significant level }\end{array}$ \\
\hline GDP & $-2.856^{* *}$ & $-3.689^{* *}$ & \\
\hline VIM & $-5.747 * * *$ & $-4.305 * * *$ & \\
\hline ER & $-4.954 * * *$ & $-4.750 * * *$ & \\
\hline FDI & & & $-5.433 * * *$ \\
\hline INT & & & $-6.657 * * *$ \\
\hline
\end{tabular}

Remarks: *** significant at $1 \%$ critical value; $* *$ Significant at $5 \%$ critical value

TABLE VII: RESUltS OF HETEROSKEDASTICITY TEST: WHITE

\begin{tabular}{|c|c|c|c|}
\hline Source & & & df \\
\hline Heteroskedasticity & 21.34 & 20 & 0.3773 \\
\hline Skewness & 6.40 & 5 & 0.2691 \\
\hline Kurtosis & 2.71 & 1 & 0.1000 \\
\hline Total & 0.45 & 26 & 0.2495 \\
\hline
\end{tabular}

\section{OLS Regression Results}

Table VIII represent the regression results and overall $\mathrm{R}^{2}$ indicates that all explanatory variables accounted for $95 \%$ of the model. Out of five variables considered there are only three variables were significant at $1 \%$ or $5 \%$ out of which the main macroeconomic variables, GDP and inflation rate are significant factors for determining BOT in Sri Lanka. The only variable, exchange rate has shown more a disparate relationship with BOT than expected (see table IX) which is also not significant in the case of the Sri Lankan economy. Final results of the model are based on the process of robust regression for rectifying the Heteroskedaticity problem and are represented as follows: TABLE VIII: OLS REGRESSION RESULTS - BASED ON ROBUST
REGRESSION METHOD

\begin{tabular}{|c|c|c|c|c|c|}
\hline Linear regression & $\begin{array}{l}\text { Number of } \\
\mathrm{F}(5,56) \\
\text { Prob }>\mathrm{F} \\
\text { R-squared= } \\
\text { Root MSE }\end{array}$ & $\begin{array}{l}\mathrm{fOBS}= \\
=245 \\
=0 .( \\
=0.95 \\
=1\end{array}$ & $\begin{array}{l}=\quad 62 \\
5.97 \\
0000 \\
64 \\
169.27\end{array}$ & & \\
\hline TB $\mid$ & $\begin{array}{l}\text { Robust } \\
\text { Std. Err. }\end{array}$ & r. & $P>|t|$ & [95\% Conf. & Interval] \\
\hline GDP |.0005239 & .0005106 & 1.03 & 0.029 & -.000499 & .0015467 \\
\hline IM | -.7219234 & .0580227 & -12.44 & 0.000 & -.8381569 & -.6056899 \\
\hline FDI | $\mathbf{. 8 1 5 7 3 7}$ & .7614665 & 1.07 & 0.289 & -.7096636 & 2.341138 \\
\hline ER | 1.774415 & 5.227253 & 0.34 & 0.736 & -8.697031 & 12.24586 \\
\hline INF | -3.366376 & 3.663184 & -0.92 & 0.042 & -10.70462 & 3.971863 \\
\hline _con 87.0678 & 364.3537 & 1.34 & 0.187 & -242.8204 & 1216.956 \\
\hline
\end{tabular}

$$
Y_{t}=f\left(\mathrm{GDP}_{t}, \mathrm{VIM}_{t}, \mathrm{FDI}_{t}, \mathrm{ER}_{t}, \mathrm{INR}_{t}\right)
$$

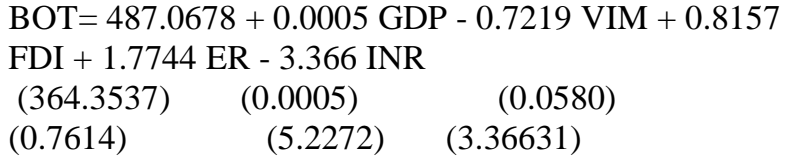

TABLE IX: SUMMARY OF THE REGRESSION RESULTS

\begin{tabular}{|l|l|l|l|}
\hline Variable & $\begin{array}{l}\text { Expected } \\
\text { Relationship }\end{array}$ & $\begin{array}{l}\text { Reported } \\
\text { Relationship }\end{array}$ & Significant level \\
\hline $\begin{array}{l}\text { Gross Domestric } \\
\text { Product }\end{array}$ & Positive & Positive & Significant at 5\% \\
\hline Volume of Imports & Negative & Negative & Significant at 1\% \\
\hline $\begin{array}{l}\text { Foreign Direct } \\
\text { Investments }\end{array}$ & Positive & Positive & Not significant \\
\hline Exchange Rate & Negative & Positive & Not significant \\
\hline Inflation Rate & Negative & Negative & Significant at 5\% \\
\hline
\end{tabular}

As anticipated, GDP shows a positive relationship with BOT and significant at 5\%confidence level (see Table IX). Based on the evidence of previous studies, this result is especially in line with [13] who investigated the Pakistan trade balance determinants and [17], who has done a comparative study between Asia and Europe for the determinants of current account deficits. Volumes of imports are the major determinant factor which directly impact on the deficit of BOT in Sri Lanka from its openness to the world. Therefore, the findings of this study are novel with regard to the volume of imports as it is getting worse than the TOB during the past 3-4 decades. As a developing economy, Sri Lanka highly depends on foreign goods irrespective of the nature of such goods. That means, when considering the breakdown of import goods it consists of major consumption goods, intermediately goods as well as goods relating to the automobile industry. Therefore, in the case of Sri Lanka, those imports are less elastic to the exchange rate as well as any price changes in the world market. However, the results are in agreement with the findings of [16] - studied trade balance in Ghana, [17], [23], and various studies carried out in the US economy by [5], [6], [24], [25]. Inflation rate measured by CCPI also represents a negative relationship with BOT as expected and significantly impacts on the BOT at 5\% confidence level. However, it was noted that "inflation rate" has not been considered as a dependent variables for the prior studies carried out with regard to trade balances. Therefore, out of the limited number of investigations based on the BOT and inflation rate, the result of the study of [5] is in line with this outcome, thereby they also concluded that a significant and negative relationship aroused among INF and BOT. The most interesting finding of this study is the results of the exchange rate. Accordingly, it indicates an insignificant positive relationship with BOT. This result completely disagrees with the findings of the studies carried out in developed countries such as the UK, USA, Australia, Canada, Switzerland as well as the studies relating to developing counties such as India, Pakistan, Saudi Arabia and Colombia. However, the result in this regard is only agreed with the investigation carried out by [16] for developing counties; he comments that he was unable to find a strong stable effect of the exchange rate on the trade balance among the 30 developing countries studied. However, the study carried out by [26] finds that real effective exchange rate (REER) does not have significant impact on improving the trade balance in Sri Lanka in the 
short term and found that it has a marginal impact in the long run. When considering FDI, it is also not significant factor of determining BOT in the Sri Lankan context even though it reports a positive relationship as expected. However, in the case of the Indian economy, FDI is a significant factor for determining trade balance according to a latest study carried out [2]

\section{CONCLUSION AND POLICY IMPLICATIONS}

This study investigated the determinants of balance of trade deficit in the Sri Lankan economy over the period 2001q1 to 2015q2. Until now, there is no published econometric study that has examined this era even though there were a few studies carried out to verify the causal effect of exchange rate and trade balance and existence of the J-curve effects. Thus, this study contributes to understanding the factors which determine the BOT in Sri Lanka during the past decade. For this purpose gross domestic product, nominal exchange rate, trade volumes of imports, foreign direct investments and Inflation rate were considered as endogenous factors. The results of the econometric model indicate that gross domestic product; volumes of imports and inflation rate have significantly impact to the BOT of Sri Lanka. The most interesting result is that the Exchange rate has no any impacted on the BOT which is not in line with the previous studies carried in other Asian countries (India, China, Pakistan, and Bangladesh) as well as in developed countries. By considering the core findings of the study, it can be concluded that the policy measures taken during the past four decades of Sri Lankan economic history for the exchange rate has less influence in terms of rectifying external balance problem in Sri Lanka. As the growth of import volumes during the observed period is substantially high, import curtailing strategies are required to be introduced in order to revise the present structural form of the BOT. Therefore, export (service) driven strategies, especially for promoting tourism which is lately considered as having a competitive advantage due to Sri Lankan's natural attractiveness rather than promoting traditional goods are also possible for policy consideration. Further, expansion of this study can be carried out by considering more exogenous factors based on the monetary approach as it would be interesting for future studies.

\section{REFERENCES}

[1] A. Weliwita and H. Tsujii, "The exchange rate \& Sri Lanka's trade deficit," Journal of Economic Development, vol. 25, no. 2, 2000.

[2] R. Sarbapriya, "An analysis of determinants of balance of trade in India," Research Jou rnal of Finance \& Accounting, vol. 3, no. 1, 2012.

[3] S. S. Kyereme, "Determinants of United States' trade balance with Australia," Applied Economics, vol. 34, pp. 1241-1250, 2002.

[4] M. Bolhasani et al., "The J-Curve: Evidence from commodity trade between Canada and the U.S.," Journal of Economics Finance, vol. 32, pp. 207-225, 2008.

[5] K. Pasula, "Monetary Non-Neutrality \& the Intertemporal Approach to the Balance of Trade: The UK Trade Balance under bretton woods," Review of International Economics, vol. 5, no. 3, 1997.

[6] O. S. Mixon, "Exchange rates and the trade balance: evidence from Germany," Atlantic Economic Journal, vol. 23, no. 2, pp. 150-162, 1995.

[7] P. M. Bodman, "The Australian trade balance and current account: A Time series perspective," International Economic Journal, vol. 11, no. 2, pp. 39-57, 1997.
[8] J. C. Brada, A. M. Kutan and S. Zhou, "The Exchange rate \& the balance of trade: The Turkish experience," Journal of Development Studies, vol. 33, no. 5, pp. 675-692, 1997.

[9] Catao and E. Falcetti, "Determinants of Argentina's external trade," Journal of Applied Economics, vol. 1, pp. 19-57, 2002.

[10] S. Hickok and J. Hung, "Explaining the persistence of the U.S. trade deficit in the late 1980s," Federal Reserve Bank of New York Quarterly Review, vol. 16, no. 4, pp.29-429, 1992.

[11] M. D. Mckenzie and R. D. Brooks, "The impact of exchange rate volatility on German-US trade flows," Journal of International Financial Markets, vol. 7, pp. 73-87, 1997.

[12] S. Mahdavi and A. Sohrabian, "The exchange value of the dollar and the US trade balance: An empirical investigation based on cointegration \& granger causality tests," Quarterly Review of Economics \& Finance, vol. 33, pp. 343-358, 1993.

[13] M. Abbas, "Effects of trade deficit on the economy of Pakistan," Interdisciplinary Journal of Contemporary Research in Business, vol. 4, no. 10, 2013.

[14] A. Wijeweera and J. A. Deskinsb," Do recent data provide evidence that the US trade deficit will correct itself?" Applied Economics Letters, vol. 17, pp. 31-35, 2010.

[15] Z. Zhang, 'Foreign exchange rate reform, the balance of trade \& economic growth: An empirical analysis for China," Journal of Economic Development, 24, no. 2, 1999.

[16] K. P. Adom and P. A. Kwakwa, "Effects of changing trade structure and technical characteristics of the manufacturing sector on energy intensity in Ghana," Renewable and Sustainable Energy Reviews, vol. 35 , pp. 475-483, 2014

[17] Aurangzeb and K. Asif, "Determinants of current account deficit: A comparison between Asia and Europe," Universal Journal of Management \& Social Sciences, vol. 2, no. 12, 2012.

[18] R. C. Hernan. Testing the short-run and long-run Exchange Rate Effects on Trade Balance: The role of Colombia. [Online]. Available: core.ac.uk/download/pdf/7077420.pdf

[19] R. Sarbapriya, "An analysis of determinants of balance of trade in India," Research Journal of Finance \& Accounting, vol. 3, no. 1, 2012

[20] J. H. Eita and M. H. Gaomab, "Macroeconomic determinants of balance of payments in Namibia," International Journal of Business and Management, vol. 7, no. 3, pp. 173-184, 2012.

[21] A. K. Rose, "Exchange rates \& the trade balance: Some evidence from developing countries," Economic Letter, vol. 34, pp. 271-275, 1991.

[22] Bahmani-Oskooee and M. Pourheydarian, "The Australian J-curve: A re-examination," International Economic Journal, vol. 5, pp. 49-58, 1991.

[23] T. Choudhry, "Exchange rate volatility and United Kingdom trade: evidence from Canada, Japan and New Zealand," Empire Econ, vol. 35 , pp. 607-619, 2008

[24] K. Aristotelous, "Exchange rate volatility, exchange rate regime and trade volume: evidence from the UK-US export function (19891999)," Economic Letters, vol. 72, pp.77-98, 2001.

[25] C. Pattighis, C. Cheong, T. Mehari, and L.V. Williams, "Exchange rate uncertainty, UK trade and Euro," Applied Financial Economics, vol. 14, pp.885-893, 2004.

[26] U. P. Alawattage, "Exchange rate, competitiveness and balance of payment performance," Central Bank of Sri Lanka Staff Studies, vol. 34, no. 1, 2002.

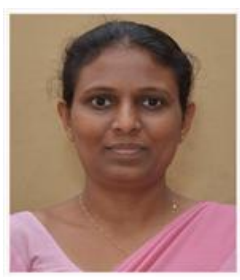

Erandi Weerasinghe is a deputy director in Central Bank of Sri Lanka. She has earned two masters degrees; one in economics from the University of Sydney, Australia and the other in financial economics from the University of Colombo, Sri Lanka. Her research areas are in international trade and financial economies

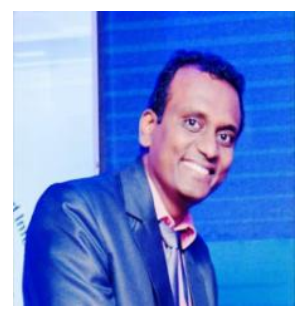

ssa Ravinda Perera is a senior lecturer in iversity of Colombo, Sri Lanka. He holds a Ph.D. $\mathrm{m}$ the Wuhan University of Technology, P.R.C in lustrial economics. His research areas are in Iovation and entrepreneurship, small business nagement, culture and management 